\title{
York Meeting of the British Association
}

$\mathrm{T}$ E British Association, after celebrating its centenary in London last year, will return this year appropriately to its birthplace, York. The annual meeting will be held there on Aug. 31Sept. 7, and the preliminary programme has just been issued. The reception room will be in the Exhibition Buildings. The inaugural meeting and evening lectures will be given in the adjoining exhibition hall, a structure which, when it served the same purpose for Ramsay, Huxley, and Spottiswoode at the jubilee meeting in 1881, was labelled as 'temporary', but through various vicissitudes has stood the test of time, and now has been amply restored since its service as a post-office sortingshed.

Under the new arrangement of the period of the presidency, Sir Alfred Ewing has already assumed that office for the present year, and the subject of his presidential address is now announced as " An Engineer's Outlook ". Many other topics of wide interest are already set down for addresses, lectures, or discussions : some of them are even intriguing. Thus a pleasing anticipation cannot but supervene when, reading on from the title of the presidential address, the eye is held by that of Prof. Miles Walker's address to Section G (Engineering) _- "The Call to the Engineer to Manage the World". Again, those who have wisely fostered co-operation between the sections should be no less satisfied than interested by the announcement of a joint meeting between Sections A (Mathematical and Physical Sciences) and $J$ (Psychology) to discuss the quantitative relation of physical stimuli and sensory events.

Among the sectional presidents, Prof. A. O. Rankine's address to Section A will deal with physics in prospecting for minerals. Stereo-chemistry will be an important topic in Section B (Chemistry), as the presidential address by Dr. W. H. Mills will deal with it, and it will also be the subject of a discussion. Prof. P. G. H. Boswell, undertaking an onerous double duty in presiding over Section C (Geology) while also a general secretary of the Association, will give his address on "The Contacts of Geology: The Ice Age and Man "; and this section also announces a joint discussion with Section $\mathrm{H}$ (Anthropology) on geology and prehistoric archæology. Primates and early man will be considered by Sections D (Zoology) and $\mathrm{H}$ (Anthropology). The subject of Lord Rothschild's address to Section $D$ is not yet announced. Prof. H. J. Fleure will address Section E (Geography) on the geographical study of society and world problems ; Prof. R. B. Forrester, Section F (Economics), on Britain's access to overseas markets ; Dr. Randall MacIver, Section H (Anthropology) on the place of archæology as a science; Prof. Beatrice Edgell, Section J (Psychology) on current constructive theories in psychology, and Prof. J. H. Priestley, Section K (Botany), on "The Growing Tree". The department of forestry under the last section will hear an address from Mr. T. B. Ponsonby on a system of forestry for the British Isles. The Association, through the work of committees and otherwise, has long striven to foster the advancement of science in schools. This will be the subject of Mr. W. M. Heller's address to Section L (Education), and, it is understood, may be also discussed at a special evening meeting. Prof. R. G. White's address to Section M (Agriculture) will deal with sheep farming. It may be added here that Section I (Physiology) will not meet in view of the simultaneous meeting of the International Physiological Congress in Rome.

Among other subjects, the interests of York, Yorkshire, and north-eastern England will rightly find a prominent place. The chemists will discuss water pollution with special reference to the present investigations in the River Tees. The relation of the millstone grit to the carboniferous limestone, the gravels of the Wolds margin, and the concealed coalfield of East Yorkshire appear in the geological programme. Section E announces a series of communications on local physical, historical, and industrial geography ; and Roman archæology will appropriately receive close consideration in Section H. The university movement and adult education in Yorkshire will be discussed in the educational section. Lastly, in so important a railway centre as York, the home also of a railway museum (which will be visited), it is fitting that Section G (Engineering) will consider railway traction by steam, oil engine, and electric power.

Evening discourses will be given by Sir Arthur Hill on plant products of the British Empire in relation to human needs, and by Mr. C. C. Paterson on uses of the photoelectric cell; while Mr. H. E. Wimperis will give an afternoon lecture, not for members exclusively, on high speed flying.

An evening reception will be given by the Lord Mayor of York (Alderman Vernon Wragge) and the Sheriff (Mr. Arnold Rowntree). Many points of interest in the neighbourhood of York (and none is richer in them) will be visited. The Yorkshire Philosophical Society, mother society of the Association, will welcome its well-grown daughter by throwing open its museum and gardens to members daily throughout the meeting. The museum itself, scene of the first meeting of the Association in 1831, and headquarters of its organisation under John Phillips, will now house Section D (Zoology) in its more modern Tempest Anderson hall.

Local officers and a committee in York already have the local arrangements fully in hand, including the important question of housing visitors. In this connexion, it is impossible to resist a quotation from the announcement of the first meeting, in 1831. Therein it was provided that on the first day of the meeting "the Managing Committee will receive, at the Museum, the names of Persons intending to be present; and will deliver tickets for the Morning and Evening Meetings, and Dinners, and references

No. 3261, VoL. 129] 
for Lodgings. The Committee will think it right to pay regard to œconomy, as well as convenience, in these arrangements." Without doubt the present local committee shares this aspiration; but members will not fail to take cognisance of a footnote to the above announcement, which appears in the
Report for 1831: "On Tuesday a public dinner was provided at Twelve Shillings a Ticket; on the other days, during the session, ordinaries at from Five to Seven Shillings a head : venison, game, and fruit being contributed...." In this respect at least there need be no fear that history will repeat itself.

\section{Obituary}

\section{Guillaume Bigourdan}

THE death of M. Bigourdan has taken from us a veteran astronomer, well known to many of his English colleagues. He attended the meeting of the Paris Academy of Sciences on Feb. 22, in his usual health, but died suddenly on Feb. 28 . Born at Sistels (Tarn-et-Garonne) on April 6, 1851, M. Bigourdan graduated in the École d'Astronomie in Paris, and was in 1877 appointed by M. Tisserand as an assistant in the Observatory at Toulouse. Here he was employed on meridian astronomy and devoted his leisure to historical studies in astronomy, which interested him all his life.

In 1879, M. Bigourdan was appointed assistant at the Paris Observatory and had charge of the large equatorial. Here he spent many years in the most assiduous observations of the positions of nebulæ and clusters. In this very trying work he determined the positions of the known nebulæ with all the precision possible from visual observations, discovered many new ones, and incidentally made measures of comets and double stars. The intention underlying these arduous observations was to provide such accurate positions of the nebulæ that future astronomers might detect small movements in these very distant objects. The results were published in the Annales of the Paris Observatory, and have since been collected in five large volumes, consisting of about three thousand pages. The gold medal of the Royal Astronomical Society was awarded to M. Bigourdan in 1919 for this monumental work.

Owing to differences between French and English observers in the values for the longitude of Paris, a re-determination was made in 1902 by M. Bigourdan and M. Lancelin working simultaneously with Sir Frank Dyson and Mr. Hollis. The results were in satisfactory accordance, and the mean differs by only $0.01^{8}$ from the recent determination made by ' wireless' transmission of time-signals. M. Bigourdan was from its commencement interested in the transmission of time by wireless, which is due to so great an extent to the initiative of General Ferrié. When Paris became the centre of the international time service, he was, until 1928, director of the Bureau.

In 1882, M. Bigourdan took part in the observations of the transit of Venus in Martinique, and he was a member of eclipse expeditions to Senegal in 1892 , to Spain in 1900 , and to Tunis in 1905 . He was for many years a member of the Bureau des Longitudes, and enriched many volumes of the Annuaire by articles on astronomical topics. His most important work on the history of astronomy was the bringing out of the "Annales célestes du dix-septième siècle" by $A$. G. Pingré. This work was completed in manuscript in 1791 and a beginning made of its publication. This went on slowly until the death of Pingré and then ceased. The manuscript was lost, but was found by $\mathrm{M}$. Bigourdan under a wrong designation in the Paris Observatory. It was printed in 1901 under the auspices of the Academy of Sciences.

M. Bigourdan was courteous and affable, and always put his point of view with vigour and vivacity. An incident which took place at the meeting of the International Astronomical Union at Rome in 1922 may be recalled. The discussion was bilingual. One of the British delegates spoke in French, which his British colleagues all understood. Whether M. Bigourdan had not been listening, or whether he wished maliciously to indicate that the French was not perfect, I do not know, but he amused his British colleagues by calling out "Traduction".

$\mathrm{He}$ married a daughter of Admiral Mouchez, and they had nine children, to whom we would offer our respectful sympathy. F. W. Dyson.

\section{News and Views}

\section{Oliver Heaviside's Work}

Ат a meeting of the Institution of Electrical Engineers on April 21, Dr. W. E. Sumpner gave the annual Kelvin Lecture, choosing as his subject the work of Oliver Heaviside. Before the lecture, the Faraday medal, the highest honour the Institution can give, was presented to Sir Oliver Lodge. Dr. Sumpner said that the work of Heaviside blended telegraphy, the earliest activity of electrical engineers, with radio communication, their latest activity. The older electricians were in the habit of applying Kelvin's formulæ, which apply only to submarine cables, to telephony. Heaviside's idea of increasing the self- induction of the line was diametrically opposed to the prevailing practice. The whole industry was in the hands of a government department very properly reluctant to try expensive experiments. Heaviside's mathematics were not easy to understand and wanted laborious study even by professed mathematicians. This was why some of his theories, although suggested several years before they were practically tried in France and America, were never actually put to the test in Great Britain. His 'distortionless' circuit enabled signals to be transmitted at high speed in submarine cables and made telephony through long cables possible. His work on the cable problem did

No. 3261, VoL. 129] 